\title{
Use of Architectural Heritage: Challenges of Preservation and Adaptation
}

\author{
Edita Riaubienė, Vilnius Gediminas Technical University
}

\begin{abstract}
The problem of the $21^{\text {st }}$ century heritage preservation is to raise the heritage to modern life. The study object is the adaptation of architectural heritage and ways of using it. The review of international and Lithuanian legislation and scientists' insights formed a controversial equation: maximum preservation, minimum changes, appropriate adaptation. The analysis of medieval castles detected prevailing adaptation conception in Lithuania ("ruins' park", "anemic") and recent signs of technological interpretation.
\end{abstract}

KEYWORDS: adaptation, architectural heritage, authenticity, heritage legislation, heritage use, interpretation, medieval castles.

The study focuses on the protection of architectural heritage at the beginning of the 21st century, when the main objective of heritage preservation in post-modern consumer society is to "raise heritage to contemporary life". Thus, the methods and terms of heritage adaptation and use for contemporary society are analyzed in the paper. The consistent analysis of international and Lithuanian heritage documents has revealed the regulatory perspective of this aspect. This paper provides a brief overview of the scientists' foresights on authenticity as the essential prerequisite for heritage preservation and its interface with heritage adaptation and use.

The cultural value of five Lithuanian medieval castles has been defined in terms of their typology, plan, spatial structure, material, technology and environment. The relations of their preservation works and authenticity, the balance of adaptation performance and heritage authenticity have been studied. The comparison with similar objects in other European countries, tendencies of their use and adaptation have revealed the perspectives of the Lithuanian situation in heritage adaptation for the needs of modern society.

\section{Aspects of Adaptation and Use in Legislation of Heritage PRESERVATION}

Reviewing international heritage documents, the main declared goals and general principles of preservation have been highlighted, as well as the approach to heritage use and application has been identified. The objectives of these documents indicate the evolution from "protect" [1], "preserve and transmit" [2; 3], "preserve authenticity and transfer" [4], towards "to provide heritage active role in society" [5], to "preserve and use for sustainable human development and quality of life" [6]. The provision of preservation still remains, but heritage transmission to future generations now must be implemented by heritage integration in postmodern, consumer society life.

The evolution of heritage protection legislation in Lithuania has showed that since 1967 the legal provisions [7] has followed the spirit of Venice Charter; heritage management activities have been separated from its use and adaptation activities [8]. There is stated that heritage is "used for scientific, educational and cultural development". In the current legislation [9], the aim of heritage protection is supplemented with aspiration of "public awareness of heritage and use of it". There is indicated that "cultural and educational tourism is one of the public uses of heritage, but it is necessary to maintain the authentic heritage form". Therefore, the provisions of heritage use in Lithuania developed from rather pragmatic to culturally adaptive, creating stronger links with the modern society.

Contemporary heritage management emphasizes active and different use of heritage resources. Scientists state that heritage use can be diverse, depending on the users' objectives and expectations. While heritage objects are usually applied to museums, the modern society is already willing to build more innovation and stronger relationship with heritage. Public can no longer be limited to passive cognition [10]. Other scientists, by accepting earlier thoughts, indicate the need to interpret heritage and thereby bring together the public, but at the same time saving heritage authenticity [11]. Lithuanian researches agree with F. Tilden's thesis, that heritage must be understood through its
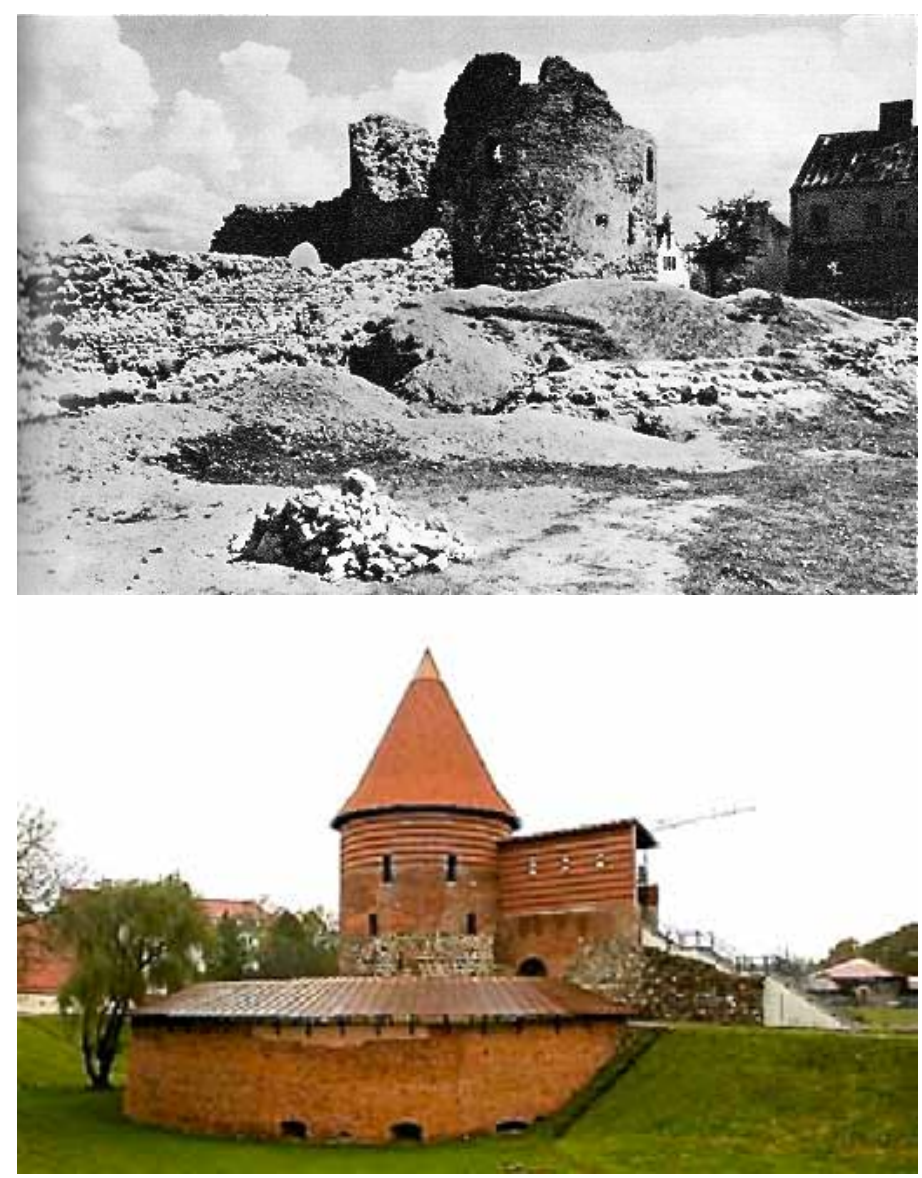

Fig. 1-2. Kaunas castle: the view of the abandoned and ruined castle in 1930; after the last restoration and adaptation in 2011. 

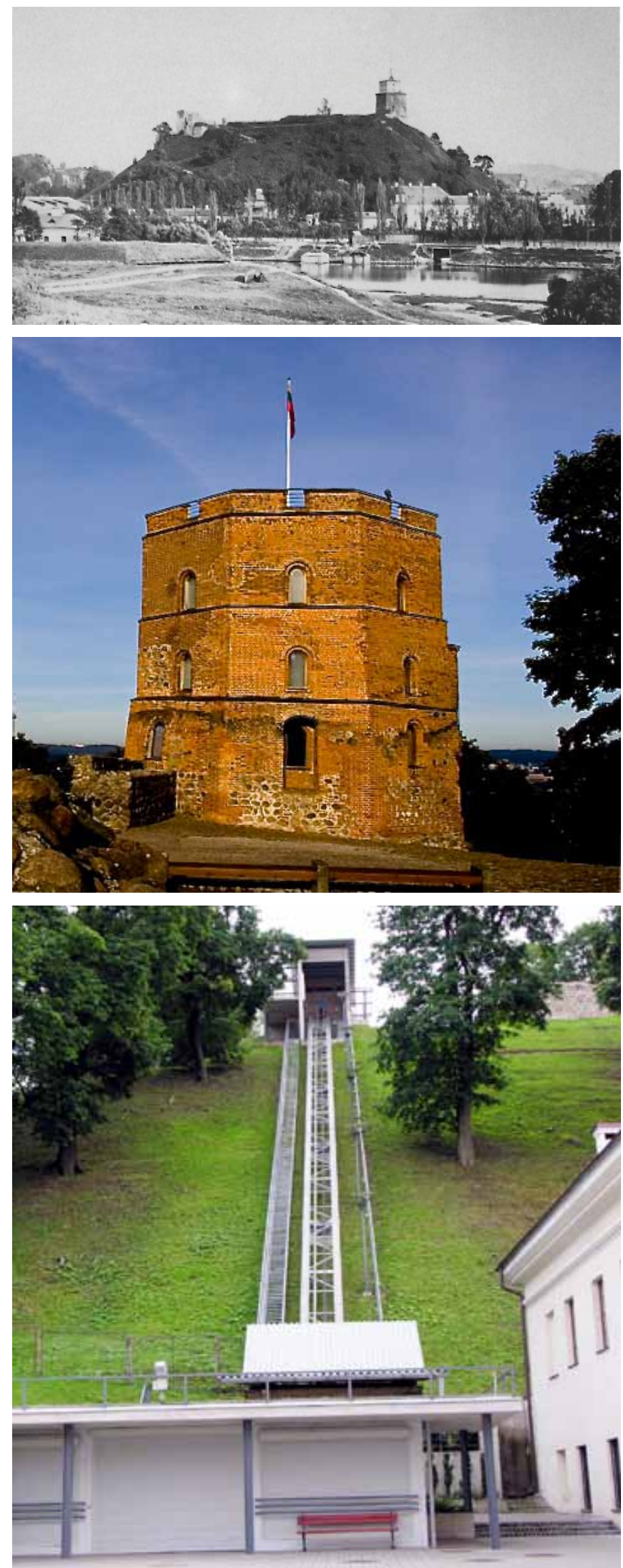

Fig. 3-5. Vilnius upper castle: the view of the castle hill in 1916; the western tower of the castle; the lift to the upper castle installed in 2003. interpretation, after understanding it must be appreciated, and while appreciated, heritage must be protected [12]. Thus, the nature of heritage preservation lies in its interpretation that can be defined as an art to clarify the heritage meaning for visitors, pointing the need to protect it [13]. Heritage perception today should cover many visitors' sensations and capacities, promote their creativity, critical thinking in terms of evaluating the past and making conjunction with the present [14]. As heritage use and adjustment for the needs of modern society have complex correlation with heritage authenticity, specialists require maximum of protection, minimal change and proper use of cultural heritage [15] and recommend separating new from old, and at the same time to maintain the consistency of the whole [11]. Although such provisions look correct, they are very difficult to implement; it refers to preservation, or changes through consensus as a certain balance between heritage authenticity and its modern use.

\section{Use and Adaptation of Lithuanian Medieval Castles}

The research of contemporary use and adaptation of the Lithuanian architectural heritage has concentrated on medieval castles, since these objects are the oldest remaining. They lost their original purpose long ago that is why their analysis would show real situation in this field. Five medieval castles have been analyzed: remaining authenticity has been studied according to primary function, shape, material, structure, technology, environment [9]. It has also been examined how the change in function and activities of new application have affected heritage authenticity. The current interpretation of objects and their consistency with heritage authenticity has been researched.

Medininkai castle environment has changed little; only integrity of form has been lost due to natural decay. Last century the castle was preserved and fragmentary restored. Currently the project of "adjustment for tourism need" is running there, providing a "complex and unique tourist attraction object". The lost form was restored (by survey data and analogues); warehouse was totally reconstructed (by historic iconography). There are also planed some novelties as the stage in the courtyard, medieval craft town, cafes, souvenir shop, and parking near the castle territory. The heritage commercialization risk appears there as its clear cultural interpretation is almost neglected.

Kaunas castle has lost most of its authenticity in various aspects: only $1 / 3$ of plan is left and $1 / 4$ of castle form remains; the environment has been damaged by the river flow and urban development. The tower was restored (1964) and adjusted for the small museum exposure. Since 2005, the tourist information center is located there, and intensive studies of castle feasibility have started. However, very little was discussed about the nature of castle use ant its interpretation; the concerns mostly related to the way how to deal with the material remains, how to reconstruct them. Now the implementation of minimum intervention project has already finished. The tower height and roof form has been designed by historical analogues. In order to differ from the authentic brick wall, the openwork masonry has been suggested, but it has totally ignored the semantics of defensive object. The new element - concrete stairs - suggests modern aesthetics, and this meets legal requirements for novelties in heritage (Figures 1-2). 
Environment of Vilnius upper castle remained most authentic, but the form and material authenticity was heavily damaged. In the early 20th century, the castle became available for public; the donjon was restored and the viewpoint was installed there (1936); the tower was applied to the museum display (1960). Only recently new elements have emerged in the castle, which meet the requirements of the modern society: the coated exit on the overview (1995), and the lift on the hill slope (2005) (Figures 3-5). These novelties reflect modern aesthetics and are measures of heritage adaptation. The given museum and city overview function satisfies optimal use of this object, regarded as a symbol of Vilnius and Lithuania. Respecting social and political importance, castle management and expressive interpretation are constantly questioned, carefully valued; therefore, the decisions of adaptation remain quite prudent, conservative in nature.

Trakai peninsula castle functioned until the mid 16th century. Now there is a great loss of authentic form and the environment has been altered by urban development. In the mid 20th century, the castle was preserved for maintaining its "ruins" image. According to the adaptation for tourism needs project (2009), the restored towers were equipped with educational classes, expositions and craft workshops. Every year the "medieval feast" is organized in the castle; this event is very popular and activates the object usability and public cognition.

Trakai island castle had defensive significance till the 15 th century, later there was Grand Duke Residence (till the 17th century). Its environment survived best of all, but more than half of the form was lost; therefore, restoration and reconstruction activities were executed using reliable historic data, analogous and hypothetic forms. The decision to rebuild was reasoned by the object great significance for state and nation, by desire to preserve the relicts and to use for the museum exposition (1962). The great wish was to restore at least one of the medieval castles in Lithuania by creating its image "what it could be" and turn the castle itself into exhibit (Figures 6-8). Currently the castle is ongoing museum activities, educational tourism, and recently there have started to organize cultural events, music festivals, concerts and other themed entertainment events that activate this heritage object participation in modern society life.

In the 20th century, medieval castles were preserved and used for cultural purposes, mainly as the spaces for museum expositions. As these objects lost most of their authentic form, reconstruction prevailed there. Visual similarity of original and restored forms testifies the cautious and shy approach that is completely opposite to the clear interpretation of history and novelty. The 21 st century has activated heritage adaptation and use for the tourism. "Live interpretation" method have raised the issue of heritage proper use and adaptation that manifests the historical pageant, reviving the spirit of historical era and highlighting the value of heritage. The recent activities of heritage adaptation in Lithuania include modern materials, technologies and forms, but these decisions are very uncertain, like feeling fear and distrust in modern aesthetics. The concept of novelty in Lithuanian heritage management is traditionally regarded as a negative phenomenon. The problem of old and new relation still exists, and it reveals the difficulties to separate and to harmonize at the same time. This situation also indicates the lack of clear strategy of heritage interpretation.
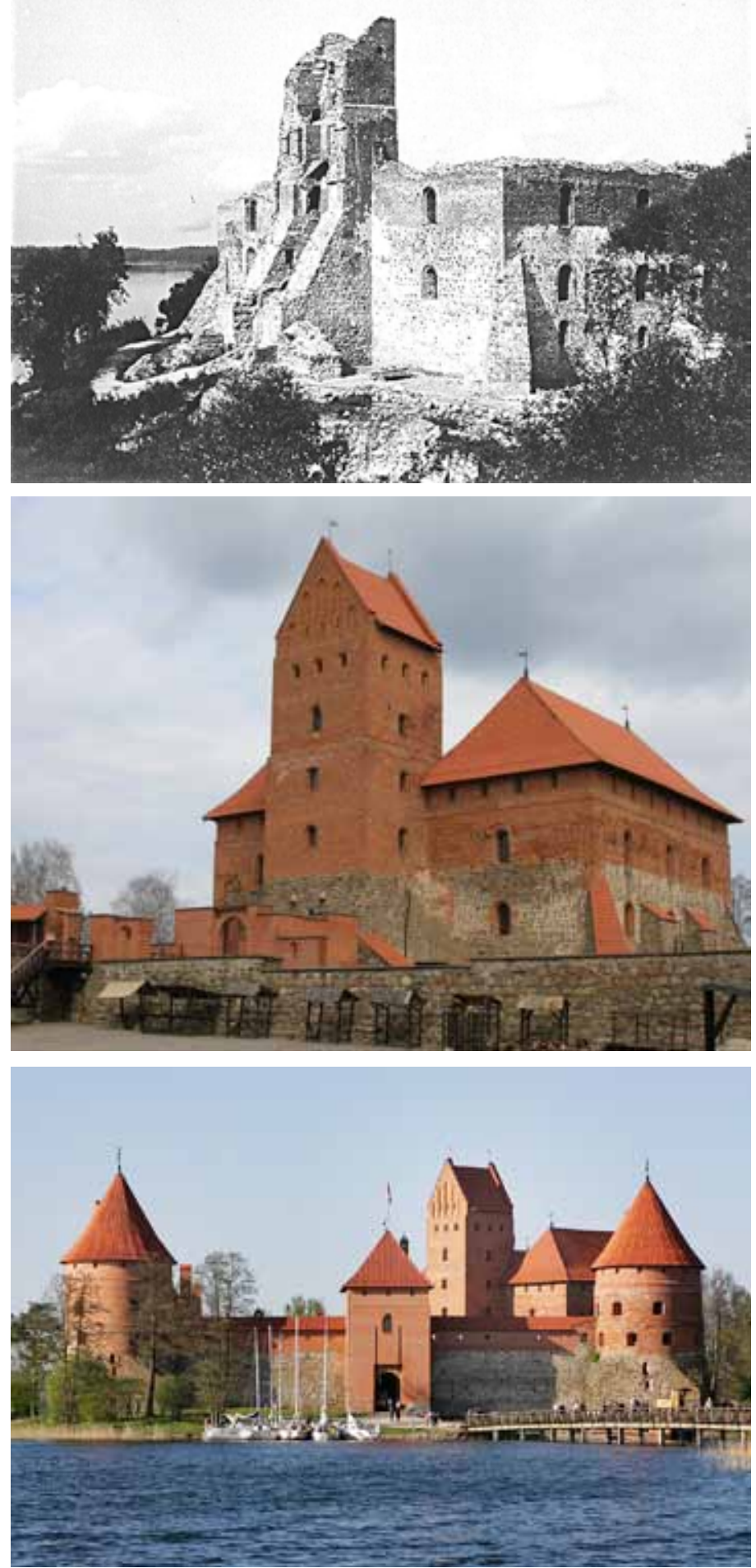

Fig. 6-8. Trakai island castle: the ruins of the castle palace in 1939; the restored palace in the castle (2012); the view of the entirely restored castle (2012).

\section{Trends of Medieval Castle Application and Use in Europe}

The study of the medieval castles in other European countries is centered on their modern use and the ways of their application for society needs. The interface of authenticity preservation and adaptation has been investigated; and the possibilities to interpret old and new, historical and contemporary, the past and the present have been observed. 

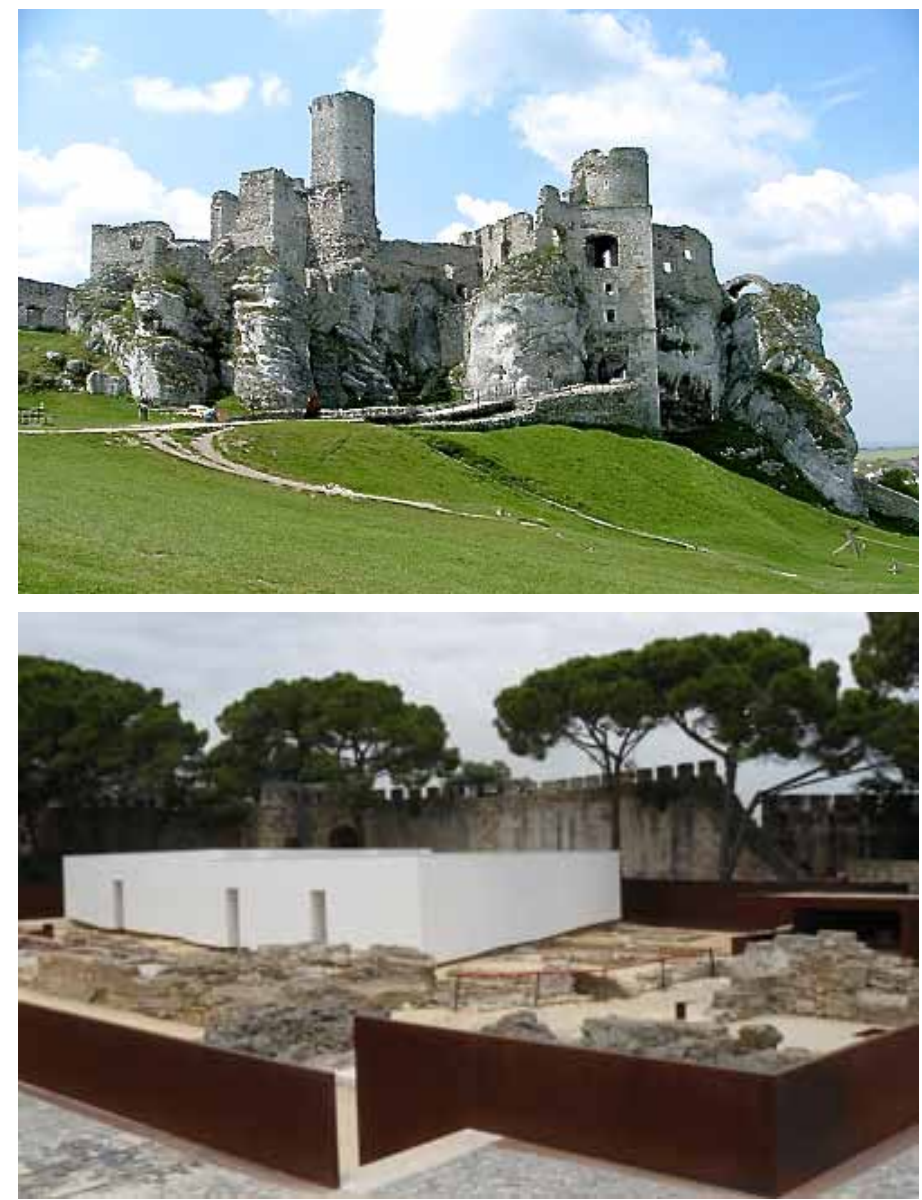

Fig. 9-10. The castles adapted according to "park of ruins" conception: Ogrodzieniec castles in Poland; Castle Praca Nova in Lisbon (2010).

"Park of ruins" concept emerged in the Romantic era, but in today's heritage preservation it can be considered the most moderate and natural heritage application method, when the object is maintained in such state, as it reached our times. The object itself becomes a showpiece, it is often used in a "passive" way; the perception of authentic object allows experiencing sense of time flow. This use and application conception is popular for the object, which has lost integrity of form, but has retained their authentic environment (Flint castle in Wales, Novogrudok in Belarus, Ogrodzieniec in Poland). Such adaptation is characterized by minimal intervention, avoiding novelties, and making emphasis on the feeling of natural evolution, change and loss. Castle Praca Nova in Lisbon (Figures 9-10) is also consistent with this concept, i.e. with introduction of new forms and materials. These new elements act as the preservation tools, and their purist forms look like they hang over the ruins. As a result, physical and time distance of the exhibited structures is made obvious.

Other conception of heritage application can be called "authenticity and innovation". In this case, heritage adaptation is based on equal dialogue of history and novelty, and implemented by composing the shapes and materials of different ages. The use of contrast principle is complex and risky, because the opposite properties "old and new", and the opposite directions "separate and connect" must be harmonized [11]. The success of this kind of heritage application illustrates the case of Koldingus castle
(1991) in Denmark and Castelgrande castle (1991) in Switzerland (Figures 11-12). The Danish castle was heavily injured; it was researched, and then entirely restored. New elements were formed from different color and size bricks; the structural interior elements (columns and stairs) of modern forms are even claimed to be a piece of art, but at the same time they respectfully leave the space for the visual perception of historic substance. Interior space is used for museum and exposure. The restoration and fragmental reconstruction of Swiss castle was executed in modern materials and monumental forms that constituted coherent whole with the historic castle. The inner space is dominated by modern aesthetics, and its monumentality perfectly fits the defensive semantics of the castle.

In addition to the above-discussed types of heritage adaptation, one more can be named as "without a clear conception". This is like an intermediate position, when objects have to play more active role in public life. Therefore, they are used without a clear or explicit view of the historicity and contemporaneity. Such objects often lack integrity, aesthetic coherence, and they cause an impression of incompleteness (Lida castle, Belarus, Ivangorod castle, Russia).

The restoration and adaptation of Malbork castle in Poland is an exceptional case. The castle was restored in traditional materials and forms. However, inner spaces manifest the concept of adaptation, where the space is divided into three groups. Authentic substance prevails in the first group; in the second group, modern expression balances with authenticity. The third group of spaces consists entirely of modern forms, because this area has been fully reconstructed; and temporary exhibition are organized here. This project demonstrates the idea of time that can be perceived through the object stages - from its original construction to the present day. Thus, the medieval castle accommodates three different interpretations - authenticity; authenticity and modernity; modernity (Past, Past + Present, Present).

\section{CONCLUSIONS}

Heritage legislation and scientific insights have highlighted the current situation, when heritage preservation and transmission to future generations is based on its close and immediate relationship with modern society, i.e. heritage must be an active participant of public everyday life. Such a situation indicates interaction of two contradictory objectives: to preserve the authentic heritage per se and to adapt it to the modern society that desires different experiences and active entertainment. This leads to a difficult task as there is not a dilemma: to preserve authenticity or to change it by adapting; to preserve or to use; to seperate or to combine, but the solution must include all factors. In this case the requirement for creative and different heritage interpretation appears, according to the aspirations and desires of society.

As interpretation is perceived as an art to clarify the meaning of a heritage object to visitors, it is a creative process that requires a lot of different skills, original ideas, creative thinking. The practice of Lithuanian heritage (medieval castles) use and adaptation is dominated by the provision of heritage preservation per se, and heritage interpretation, disclosure and way of its adaptation are perceived as a secondary, minimal 
measure. That is why even today in heritage adaptation practice the retrospective forms, traditional, already tested solutions are used that are not irrelevant to modern society (muzeologisation of the restored and reconstructed heritage). Lithuanian heritage adaptation process lacks the clear representation of relationship of past and present; that is rather successfully implemented in other European countries by the concepts of "authenticity and innovations". Heritage adaptation and interpretation activities in Lithuania poorly cover public opinion and are mostly guided by institutional decisions; such a situation is not topical. Over the last decade positive changes have emerged: the method of "live interpretation" is increasingly being used in the Lithuanian medieval castles that manifest as historical pageant, artistic performances, concerts and craft fairs.

\section{REFERENCES}

1. The Athens Charter for the Restoration of Historic Monuments, 1931 [online]. ICOMOS [cited 05.01.2012]. http://www.icomos.org/index.php/ en/charters-and-texts?id=167:the-athens-charter-for-the-restoration-ofhistoric-monuments\&catid=179:charters-and-standards

2. European Charter of the Architectural Heritage [online]. Council of Europe. 1975 [cited 05.01.2012.]. http://www.unescobkk.org/fileadmin/ user_upload/culture/cultureMain/Instruments/European_Charter.pdf

3. Convention for the Protection of the Architectural Heritage of Europe [online]. Council of Europe. 1985 [cited 05.01.2012.]. http://conventions. coe.int/treaty/en/treaties/html/121.htm

4. International Charter for the Conservation and Restoration of Monuments and Sites (The Venice Charter) [online]. ICOMOS. 1964 [cited 05.01.2012.] http://www.international.icomos.org/charters/venice_e.pdf

5. Recommendation concerning the Protection, at National Level, of the Cultural and Natural Heritage [online]. UNESCO. 1972 [cited 17.01.2012.]. http://portal.unesco.org/en/ev.php-URL_ID=13087\&URL_ DO=DO_TOPIC\&URL_SECTION $=201 . \mathrm{html}$

6. Convention on the Value of Cultural Heritage for Society (Faro) [online] Council of Europe. 2005 [cited 05.01.2012.]. http://conventions.coe.int/ Treaty/EN/Treaties/Html/199.htm

7. Kultūros paminklu apsaugos istatymas (1967) ir jo taikymo instrukcija (1972) [online]. Vilnius, [cited 17.01.2012.]. http://www3.lrs.lt/pls/inter/ w5_show?p_r=883\&p_d=8576\&p_k=1 ("Cultural Heritage Protection Law”)

8. Istorijos ir kultūros paminklų apsaugos ir naudojimo nuostatai. LTSR AT ir Vyriausybés žinios, 1982, Nr.36, 796-813 p. (Historical and Cultural Monuments Protection and Use Regulations)

9. LR nekilnojamojo kultūros paveldo apsaugos istatymas [online]. KPD. 2005 [cited 17.01.2012.]. http://www.kpd.lt/KPD20050609iNr259 ("Immovable Cultural Heritage Protection Act")

10. Ashworth G., Howard P. Europos paveldas. Planavimas ir valdymas. Vilnius: Versus Aurea. 2008. 199 p.

11. Feilden, B.M., Jokilehto, J. Pasaulio kultūros paveldo vietu bei vietoviu priežiūros gairès. Vilnius: Savastis, 1998. $160 \mathrm{p}$.

12. Tilden, F. Interpreting our heritage. Chapel Hill: University of North Carolina Press. 2008. 224 p.

13. Aldridge, D. How the ship of interpretation was blown off course in the tempest: some philosophical thoughts. Heritage interpretation, 1989, vol. 1, p. 64-87.

14. Čepaitiene R. Paveldosauga globaliame pasaulyje. Vilnius: LII, 2011.376 p.

15. Glemža, J. Nekilnojamojo kultūros paveldo apsauga ir tvarkymas. Vilnius: VDA, 2002. p. 252.
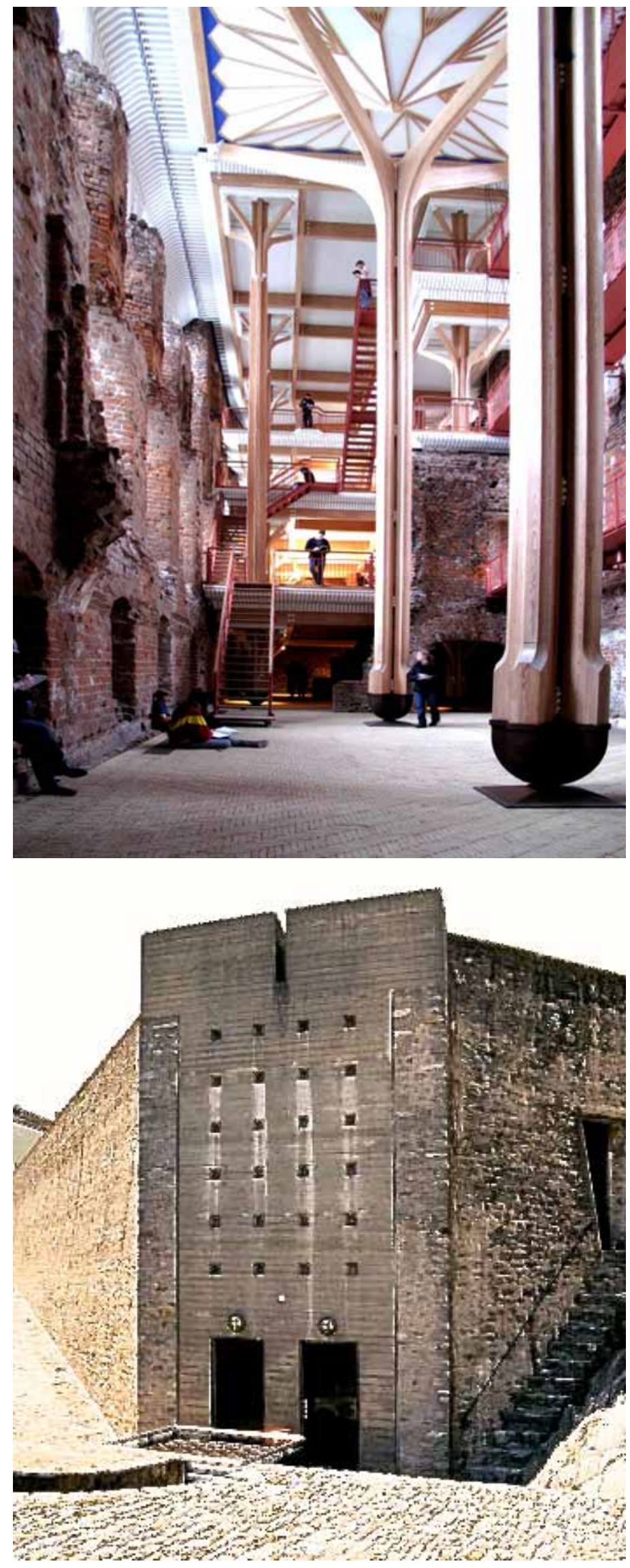

Fig. 11-12. The castles adapted according to the "authenticity and innovation" conception: the interior of Koldingus castle in Denmark, restored and adapted in 1991; the entrance to the Castelgrande castle in Switzerland (restored in 1991). 


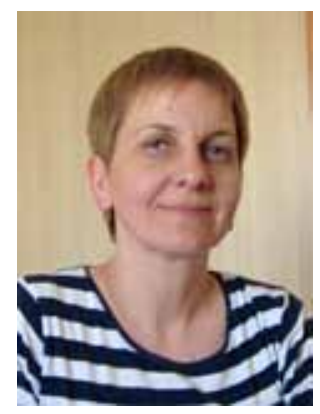

Edita Riaubienè (b. 1967, Vilnius), First degree in Architecture (1994), Vilnius Gediminas Technical University); Master of Architecture (1997, VGTU), Doctor of Humanities (Arts) (2003, VGTU)

After the doctoral thesis was defended ("Architectural heritage preservation in Lithuania (1918-2000): legal possibilities and results of conservation", 2003) started lecturing in the Department of Architecture Fundamentals and Theory (VGTU), and in 2004 became the ASSOCIATE PROFESSOR. 2003-2011 was working as VICE DEAN of the Faculty of Architecture (VGTU). The member of the „Board of the evaluation of immovable heritage" in Ministry of Culture of Lithuania, Department of Cultural Heritage (2005-2011).

Guest lectures at the "Roma la Sapienza" University, Roma (2004), Gotland University in Visby (2005), Czech Technical University, Prague (2005), "Moderna" University in Lisbon (2007), "Kyungpook National University", Daegu, South Korea (2009).

The research interest covers theory of cultural heritage and architectural heritage preservation, and architectural theory and history. Participated in 6 national conferences $(2000,2001,2003,2006,2010)$ and 6 international conferences in Tallinn (1999), Oulu (2000), Helsingborg (2002), Gotland (2005), Vilnius (2007), Riga (2008). Author of 13 scientific publications: 8 of them are in the national scientific journals $(2000,2001,2003,2007,2009,2010)$, others are in the international scientific publications $(2000,2004,2007)$; more than 60 articles in the Lithuanian architectural professional press; book for studies "Doors in Architecture" (2009).

Published articles:

- Riaubiené, E. The Evaluation Criteria of Cultural Heritage in Lithuania. Wooden Architecture in Northern Europe. Szczecin: Wydawnictwo Hogben, 2004, p. 159-164. ISBN 83-916682-9-0

- Riaubiené, E. Vilnius architectural heritage preservation and reconstruction phenomenon. Inventories and heritage management. Visby: Gotland University, 2007, p. 93-101. ISBN 9789197580052

- Riaubienė, E. Evolution and trends of understanding of authenticity in heritage preservation. Urban heritage: research, interpretation, education. Vilnius: Technika, 2007, p. 77-82. ISBN 9789955281771

\section{Contact Data}

Edita Riaubienè

Vilnius Gediminas Technical University, Faculty of Architecture

Address: Pylimo 26/1, Vilnius 01132, Lithuania

Phone: +37061216573

E-mail: edita.riaubiene@vgtu.lt 